\title{
Risk and Time Preferences: Linking Experimental and Household Survey Data from Vietnam
}

\author{
By Tomomi Tanaka, Colin F. Camerer, and Quang Nguyen*
}

A fundamental question in development economics is the extent to which economic success is linked to basic features of human preferences. If people are extremely averse to financial risk, they may be reluctant to create businesses that may have inherently risky cash flows. If people are impatient, they may be reluctant to invest and educate their children. Taken together, risk aversion and impatience may explain, in part, why some people remain poor.

We conducted experiments in Vietnamese villages to directly measure risk and time preferences of individuals, and investigated how these preferences correlate with economic circumstances. Vietnam has several advantages as a field site:

(i) Access to a 2002 living standard survey enabled us to link detailed survey responses from individuals directly to experimental responses by the same individuals.

(ii) Most Vietnamese villagers are poor but literate. As a result, it is easy to motivate them with modest financial stakes and to ensure they comprehend instructions.

(iii) The rise of household businesses in the market economy has created substantial variation in income. This income variation can be correlated with preference measures.

In any cross-sectional study like this, it is difficult to infer the direction of causality from correlation: do preferences cause economic circumstances (e.g., through business formation), or do circumstances create preferences as described by Samuel Bowles (1998)? An ideal study would use randomized assignment of individuals to economic circumstances. As an alternative, we employ an instrumental variable approach, using rainfall and household head's ability to work at the time of survey, which are unlikely to be correlated with preferences, as instrumental variables for income.

Beside contributing new data, our paper makes a methodological contribution to experimental development economics. Most previous experiments conducted in the field tested models of risk and time preferences that can be characterized by one parameter. See Juan-Camilo Cardenas

* Tanaka: School of Global Studies, Arizona State University, PO Box 875102, Tempe, AZ 85287-5102 (e-mail: tomomi.tanaka@asu.edu); Camerer: Division for the Humanities and Social Sciences, California Institute of Technology, MC 228-77, Pasadena CA 91125 (e-mail: camerer@hss.caltech.edu); Nguyen: Groupe d'Analyse et de Théorie Economique (GATE), CNRS, Faculté de Sciences Économiques et de Gestion, Université Lumière (Lyon 2) (e-mail: nguyenq@gate.cnrs.fr). This research was supported by a Behavioral Economics Small Grant from the Russell Sage Foundation, Foundation for Advanced Studies on International Development, and internal Caltech funds to author Camerer. Comments from participants at the ESA meeting (October 2005), SEA meeting (November 2005), SJDM (November 2005), ASSA meeting (January 2007), audiences at Columbia, NYU, Bocconi, Emory, Hawaii, Caltech, UCSC, Claremont McKenna, Guelph, Carleton, Arizona State, a conference at UT-Dallas, and five thoughtful anonymous referees were helpful. Thanks to our research coordinators, Phan Dinh Khoi, Huynh Truong Huy, Nguyen Anh Quan, Nguyen Mau Dung, and research assistants, Bui Thanh Sang, Nguyen The Du, Ngo Nguyen Thanh Tam, Pham Thanh Xuan, Nguyen Minh Duc, Tran Quang Trung, and Tran Tat Nhat. We also thank Nguyen The Quan of the General Statistical Office for allowing us access to the 2002 household survey data. 
and Jeffrey Carpenter (2008) for a review. These models often fit experimental data in Western educated populations (Shane Frederick, George Loewenstein, and Ted O’Donoghue 2002; Chris Starmer 2000) and field data (Camerer 2000) less well than models with multiple components of risk and time preferences. For example, in expected utility (EU) theory, risk preferences are characterized solely by the concavity of a utility function for money. But if risky choices express prospect theory preferences (Daniel Kahneman and Amos Tversky 1979), then utility concavity is not the only parameter influencing risk preferences; nonlinear weighting of probabilities, and aversion to loss compared to gain, also influence risk preferences. Our instruments are designed to measure these three parameters of prospect theory, rather than just one in EU.

Similarly, we measure three parameters in a general time discounting model (Jess Benhabib, Alberto Bisin, and Andrew Schotter 2007), rather than measuring a single exponential discount rate as in most other studies. If the exponential model is an adequate approximation, then our richer instruments will deliver parameter values of the extra variables that affirm the virtue of the simpler exponential.

Before proceeding to design details and results, it is useful to discuss how our approach compares to other field experiments. Field experiments in development are powerful tools for policy evaluation because they can randomize treatments in naturally occurring decision making to see how well a specific policy works in a specific setting with a proper control group (see Esther Duflo 2005 for a review). For example, Nava Ashraf, Dean Karlan, and Wesley Yin (2006) found that women who displayed lower discount rates in a hypothetical-question survey were more likely to open a commitment savings account offered by a bank in the Philippines.

Our approach is different. Our study is designed to collect preference measures experimentally and correlate those measures with demographic and economic variables (income, in particular) from the previous household survey. The goal is to contribute basic tools for field experimentation and to generate tentative observations about the correlation between preferences and economic circumstances. No single result will be as conclusive as more targeted studies that explore the effect of a specific policy. Nevertheless, the policy-specific approach and our broad approach are complementary. Targeted studies like that of Ashraf et al. tell broader studies, like ours, what to look for. And broader studies give a rich set of tentative results for more targeted studies to explore more carefully. Accumulation of empirical regularity will come most quickly from conducting both types of studies.

\section{Selection of Research Sites and Research Methods}

In July-August 2005, risk and time discounting experiments were conducted with members of households who were previously interviewed during a 2002 living standard measurement survey. ${ }^{1}$ In the 2002 survey, 25 households were interviewed in each of 142 rural villages in the Mekong Delta (in the south) and 137 rural villages in the Red River Delta (in the north). ${ }^{2}$ From these, we chose nine villages, five villages in the south and four villages in the north, with substantial differences in mean village income and market access. Some descriptive statistics about the nine experimental village sites are given in Table 1. The southern villages are indexed by S1-S5 (where

\footnotetext{
${ }^{1}$ A discrete trust game was conducted before the risk and time discounting experiments. Trust outcomes were not revealed until the end of the session and are reported elsewhere.

2 The 2002 living standard survey covers total 354,360 households in Vietnam. According to the local government officials in our research sites, lists of all households in selected villages were submitted to district offices, and households were randomly selected from the lists for the survey.
} 
TABle 1-Descriptive Statistics

\begin{tabular}{|c|c|c|c|c|c|c|c|c|c|}
\hline & S1 & $\mathrm{S} 2$ & S3 & S4 & S5 & N1 & $\mathrm{N} 2$ & N3 & N4 \\
\hline Total number of subjects & 22 & 16 & 18 & 21 & 21 & 17 & 22 & 24 & 20 \\
\hline Ethnic Chinese subjects & 9 & 1 & 0 & 0 & 0 & 0 & 0 & 0 & 0 \\
\hline \multicolumn{10}{|c|}{ Mean household income in 2002 (1 million dong) } \\
\hline & 36.6 & 35.8 & 20.3 & 18.5 & 15.0 & 28.0 & 17.5 & 9.1 & 7.2 \\
\hline Age (mean) & 47.7 & 44.6 & 48.8 & 42.8 & 47.9 & 55.1 & 42.5 & 49.9 & 48.6 \\
\hline Gender $(1=$ male $)($ mean $)$ & 0.59 & 0.88 & 0.83 & 0.71 & 0.81 & 0.47 & 0.36 & 0.50 & 0.50 \\
\hline Education (years) (mean) & 7.2 & 7.1 & 8.4 & 6.0 & 5.0 & 7.5 & 8.0 & 4.8 & 7.6 \\
\hline Literacy rate (mean) & 0.95 & 0.94 & 0.95 & 0.95 & 0.91 & 0.89 & 0.95 & 0.83 & 0.90 \\
\hline Distance to nearest market & 0.0 & 5.0 & 0.0 & 4.2 & 0.0 & 0.0 & 1.0 & 3.0 & 0.3 \\
\hline Rainfall (mm) & 1,442 & 2,328 & 1,442 & 1,202 & 1,202 & 1,399 & 1,399 & 1,442 & 1,442 \\
\hline \multicolumn{10}{|c|}{ Number of household heads unable to work at the time of survey } \\
\hline & 1 & 0 & 0 & 1 & 1 & 0 & 1 & 1 & 2 \\
\hline \multicolumn{10}{|c|}{ Daily wage for male labor for harvesting (1,000 dong) } \\
\hline & - & - & 30 & 30 & 30 & 18 & 18 & 20 & 20 \\
\hline
\end{tabular}

$\mathrm{S} 1$ indexes the highest village wealth and S5 indexes the lowest), and northern villages are indexed by $\mathrm{N} 1-\mathrm{N} 4 .^{3}$

A week before the experiments, research coordinators contacted local government officials in each research site and asked them to invite one person from each of the 25 previously surveyed households to the experiments. Experiments started at approximately 9 AM in the morning, and lasted about four hours. Subjects were given instructions and separate record sheets for each game. Illiterate subjects ( 8 percent) were given verbal instruction by research assistants. Subjects who had difficulty completing record sheets by themselves were also helped by research assistants who carefully avoided giving specific instructions about how to answer. The average experimental earning for three games was 174,141 dong (about 11 dollars) ${ }^{4}$, roughly 6 to 9 days' wages for casual unskilled labor.

\section{Risk}

\section{A. Previous Findings}

Ravi Kanbur and Lyn Squire (2001) describe the risk attitude of the poor as "a feeling of vulnerability." Market fluctuations and natural disasters could put these villagers in a state of having little or losing what little they have. Empirical evidence suggests wealthier households invest in more risky productive activities and earn higher returns (Mark R. Rosenzweig and Hans P. Binswanger 1993). These premises are consistent with decreasing absolute risk aversion in EU theory; wealthier people are willing to take more risk than poorer people.

However, previous experimental studies conducted in developing countries give mixed results on wealth and risk preferences. Binswanger $(1980,1981)$ and Paul Mosley and Arjan Verschoor (2005) find no significant association between risk aversion and wealth. Uffe Nielsen (2001) finds positive relations between wealth and risk aversion, while Matte Wik et. al. (2004) and Mahmud Yesuf (2004) find negative correlations. However, they used EU and mix gain-only and gain-loss

\footnotetext{
${ }^{3}$ Villages S1 and S3 are in Can Tho City, Village S2 is in Ca Mau Province, Villages S4 and S5 are in Tra Vinh Province, Villages N1 and N2 are in Vinh Phuc Province, and Villages N3 and N4 are in Thai Binh Province.

${ }^{4}$ The exchange rate between the Vietnamese dong and US dollar does not fluctuate very much. On July 23, 2005, the exchange rate was 15,880 dong for one dollar, while it was 15,947 dong for one dollar on July 23, 2002.
} 
gambles in their analysis, making it difficult to tell whether risk aversion comes solely from the concavity of utility function.

\section{B. Measurement of Prospect Theory Parameters}

We consider prospect theory as an alternative theoretical framework to EU, and conduct experiments with lotteries involving both gains and losses. We use cumulative prospect theory and the one-parameter form of Drazen Prelec's (1998) axiomatically derived weighting function. The values of prospects are $v(y)+\pi(p)(v(x)-v(y)$ ) (for $x y>0$ and $|x|>|y|$ ) or $v(y)+\pi(p) v(x)+\pi(q) v(y)$, where $p$ and $q$ are the probabilities of outcomes $x$ and $y$. We assume a piecewise power function for value, $v(x)=x^{\sigma}$ for gains $x>0$, and $v(x)=-\lambda(-x)^{\sigma}$ for losses $x$ $<0$. The probability weighting function is $\pi(p)=1 / \exp [\ln (1 / p)]^{\alpha}$.

Parameters $\sigma$ and $\lambda$ represent concavity of the value function, and the degree of loss aversion. The probability weighting function is linear if $\alpha=1$, as it is in EU. If $\alpha<1$, the weighting function is inverted S-shaped, i.e., individuals overweight small probabilities and underweight large probabilities, as shown by Tversky and Kahneman (1992). If $\alpha>1$, then the weighting function is S-shaped, i.e., individuals underweight small probabilities and overweight large probabilities. The above model reduces to EU (with a reflected utility function at zero) if $\alpha=1$ and $\lambda=1$.

To elicit the three prospect theory parameters, we designed three series of paired lotteries as shown in Table 2. Each row is a choice between two binary lotteries, A or B. We enforced monotonic switching by asking subjects at which question they would "switch" from Option A to Option B in each series. They can switch to Option B starting with the first question, and they do not have to switch to Option B at all. ${ }^{5}$ After they complete three series of questions with the total of 35 choices, we draw a numbered ball from a bingo cage with 35 numbered balls to determine which row of choice will be played for real money. We then put back ten numbered balls in the bingo cage and played the selected lottery.

The difference in expected value between the lotteries (A relative to B) is shown in the right column. As one moves down the rows, the higher payoff in Option B increases and everything else is fixed. The choices are carefully designed so any combination of choices in the three series determines a particular interval of prospect theory parameter values. Table 3 illustrates the combinations of approximate values of $\sigma, \alpha$, and $\lambda$ for each switching point. "Never" indicates the cases in which a subject does not switch to Option B (i.e., always chooses A). The switching points in Series 1 and 2 jointly determine $\sigma$ and $\alpha$. For example, suppose a subject switched from Option $\mathrm{A}$ to $\mathrm{B}$ at the seventh question in Series 1 . The combinations of $(\sigma, \alpha)$ that can rationalize this switch are $(0.4,0.4),(0.5,0.5),(0.6,0.6),(0.7,0.7),(0.8,0.8),(0.9,0.9)$, or $(1,1)$. Now suppose the same subjects also switched from Option A to B at the seventh question in Series 2. Then the combinations of $(\sigma, \alpha)$ that rationalize that switch are $(0.8,0.6),(0.7,0.7),(0.6,0.8),(0.5,0.9)$, or $(0.4,1)$. By intersecting these parameter ranges from Series 1 and 2 , we obtain the approximate values of $(\sigma, \alpha)=(0.7,0.7)$. Predictions of $(\sigma, \alpha)$ for all possible combinations of choices are given in Table A1 in the Web Appendix (available at http://www.aeaweb.org/articles.php?doi=10.1257/ aer.100.1.557).

The loss aversion parameter $\lambda$ is determined by the switching point in Series 3. Notice that $\lambda$ cannot be uniquely inferred from switching in Series 3. Questions in Series 3 were constructed to make sure that $\lambda$ takes similar values across different levels of $\sigma$. Table 3 shows the range of $\lambda$ for each switching point for three values $\sigma=0.2,0.6$, and 1 .

\footnotetext{
${ }^{5}$ The instructions gave three examples. In one example a subject switches at the sixth question, in one example the subject chooses Option A for all questions, and in one example the subject chooses Option B for all questions. The three examples were given to help ensure that subjects do not feel that they are forced to switch.
} 
Table 2-Three Series of Pairwise Lottery Choices (in 1,000 dong)

\begin{tabular}{|c|c|c|c|c|}
\hline \multicolumn{2}{|c|}{ Option A } & \multicolumn{2}{|c|}{ Option B } & \multirow[t]{2}{*}{ Expected payoff difference $(\mathrm{A}-\mathrm{B})$} \\
\hline Series 1 & & & & \\
\hline Balls 1-3 & Balls 4-10 & Ball 1 & Balls 2-10 & \\
\hline 40 & 10 & 68 & 5 & 7.7 \\
\hline 40 & 10 & 75 & 5 & 7.0 \\
\hline 40 & 10 & 83 & 5 & 6.0 \\
\hline 40 & 10 & 93 & 5 & 5.2 \\
\hline 40 & 10 & 106 & 5 & 3.9 \\
\hline 40 & 10 & 125 & 5 & 2.0 \\
\hline 40 & 10 & 150 & 5 & -0.5 \\
\hline 40 & 10 & 185 & 5 & -4.0 \\
\hline 40 & 10 & 220 & 5 & -7.5 \\
\hline 40 & 10 & 300 & 5 & -15.5 \\
\hline 40 & 10 & 400 & 5 & -25.5 \\
\hline 40 & 10 & 600 & 5 & -45.5 \\
\hline 40 & 10 & 1,000 & 5 & -85.5 \\
\hline 40 & 10 & 1,700 & 5 & -155.5 \\
\hline \multicolumn{5}{|l|}{ Series 2} \\
\hline Balls 1-9 & Ball 10 & Balls 1-7 & Balls 8-10 & \\
\hline 40 & 30 & 54 & 5 & -0.3 \\
\hline 40 & 30 & 56 & 5 & -1.7 \\
\hline 40 & 30 & 58 & 5 & -3.1 \\
\hline 40 & 30 & 60 & 5 & -4.5 \\
\hline 40 & 30 & 62 & 5 & -5.9 \\
\hline 40 & 30 & 65 & 5 & -8.0 \\
\hline 40 & 30 & 68 & 5 & -10.1 \\
\hline 40 & 30 & 72 & 5 & -12.9 \\
\hline 40 & 30 & 77 & 5 & -16.4 \\
\hline 40 & 30 & 83 & 5 & -20.6 \\
\hline 40 & 30 & 90 & 5 & -25.5 \\
\hline 40 & 30 & 100 & 5 & -32.5 \\
\hline 40 & 30 & 110 & 5 & -39.5 \\
\hline 40 & 30 & 130 & 5 & -53.5 \\
\hline \multicolumn{5}{|l|}{ Series 3} \\
\hline Balls 1-5 & Balls 6-10 & Balls 1-5 & Balls 6-10 & \\
\hline 25 & -4 & 30 & -21 & 6.0 \\
\hline 4 & -4 & 30 & -21 & -4.5 \\
\hline 1 & -4 & 30 & -21 & -6.0 \\
\hline 1 & -4 & 30 & -16 & -8.5 \\
\hline 1 & -8 & 30 & -16 & -10.5 \\
\hline 1 & -8 & 30 & -14 & -11.5 \\
\hline 1 & -8 & 30 & -11 & -13.0 \\
\hline
\end{tabular}

\section{Empirical Results}

Figure 1 shows the distributions of choices made by subjects in Series 1 and 2 . The numbers in the axes correspond to the switching points in Series 1 and $2 .{ }^{6}$ The height of a cone represents the number of subjects who switched at that particular combination of switching points in Series 1 and 2. Black cones represent the choices that are consistent with EU. There are not many subjects whose choices are consistent with EU. The mean estimated values of $(\sigma, \alpha)$ are $(0.59,0.74)$ and $(0.63,0.74)$ in the south and north, respectively. Elaine Liu $(2008)$ replicated this risk experiment

\footnotetext{
${ }^{6}$ Switching point 15 implies the subject never switched in that series.
} 
Table 3-Switching Point (Question at which Preference Switches from Option A to Option B) and APPROXIMATIONS OF $\sigma, \alpha$ AND $\lambda$

\begin{tabular}{|c|c|c|c|c|c|c|c|c|c|c|c|c|c|c|c|}
\hline \multicolumn{8}{|c|}{ Series 1 (questions 1-14) } & \multicolumn{8}{|c|}{ Series 2 (questions 15-28) } \\
\hline$\sigma^{\alpha}$ & 0.4 & 0.5 & 0.6 & 0.7 & 0.8 & 0.9 & 1.0 & $\sigma^{\alpha}$ & $.0 .4 \ldots$ & 0.5 & 0.6 & 0.7 & 0.8 & 0.9 & 1.0 \\
\hline 0.2 & 9 & 10 & 11 & 12 & 13 & 14 & never & 0.2 & never & 14 & 13 & 12 & 11 & 10 & 9 \\
\hline 0.3 & 8 & 9 & 10 & 11 & 12 & 13 & 14 & 0.3 & 14 & 13 & 12 & 11 & 10 & 9 & 8 \\
\hline 0.4 & 7 & 8 & 9 & 10 & 11 & 12 & 13 & 0.4 & 13 & 12 & 11 & 10 & 9 & 8 & 7 \\
\hline 0.5 & 6 & 7 & 8 & 9 & 10 & 11 & 12 & 0.5 & 12 & 11 & 10 & 9 & 8 & 7 & 6 \\
\hline 0.6 & 5 & 6 & 7 & 8 & 9 & 10 & 11 & 0.6 & 11 & 10 & 9 & 8 & 7 & 6 & 5 \\
\hline 0.7 & 4 & 5 & 6 & 7 & 8 & 9 & 10 & 0.7 & 10 & 9 & 8 & 7 & 6 & 5 & 4 \\
\hline 0.8 & 3 & 4 & 5 & 6 & 7 & 8 & 9 & 0.8 & 9 & 8 & 7 & 6 & 5 & 4 & 3 \\
\hline 0.9 & 2 & 3 & 4 & 5 & 6 & 7 & 8 & 0.9 & 8 & 7 & 6 & 5 & 4 & 3 & 2 \\
\hline 1.0 & 1 & 2 & 3 & 4 & 5 & 6 & 7 & 1.0 & 7 & 6 & 5 & 4 & 3 & 2 & 1 \\
\hline
\end{tabular}

Series 3 (questions 29-35)

\begin{tabular}{lccc} 
Switching question & $\sigma=0.2$ & $\sigma=0.6$ & $\sigma=1$ \\
\hline 1 & $\lambda>0.14$ & $\lambda>0.20$ & $\lambda>0.29$ \\
2 & $0.14<\lambda<1.26$ & $0.20<\lambda<1.38$ & $0.29<\lambda<1.53$ \\
3 & $1.26<\lambda<1.88$ & $1.38<\lambda<1.71$ & $1.53<\lambda<1.71$ \\
4 & $1.88<\lambda<2.31$ & $1.71<\lambda<2.25$ & $1.71<\lambda<2.42$ \\
5 & $2.31<\lambda<4.32$ & $2.25<\lambda<3.73$ & $2.42<\lambda<3.63$ \\
6 & $4.32<\lambda<5.43$ & $3.73<\lambda<4.82$ & $3.63<\lambda<4.83$ \\
7 & $5.43<\lambda<9.78$ & $4.82<\lambda<9.13$ & $4.83<\lambda<9.67$
\end{tabular}

Note: Bold indicates choices compatible with EU $(\alpha=1)$ and risk aversion.

with Chinese farmers and estimated average values $(0.48,0.69)$, which are reasonably close. The average derived value of $\alpha$ is significantly different from one at the 1 percent significance level by $t$-test, rejecting EU in favor of inverted-S shaped probability weighting (see Ming Hsu et al. (2009) for a review and neural measures). We regressed the curvature of the utility function $(\sigma)$ using OLS regressions, and loss aversion $(\lambda)$ by interval regressions using maximum likelihood techniques against individual-specific variables. ${ }^{7}$ We first ran regressions using household income as an independent variable.

The regression results are shown in columns 1 and 3 of Table 4. Looking first at $\sigma$ (curvature of the utility function), the strongest effects suggest subjects who are more educated and older are more risk averse. The estimation result for loss aversion $(\lambda)$ shows ethnic Chinese are less loss averse and people living in the south are more loss averse. Household income is not significantly correlated with either $\sigma$ or $\lambda$.

Having learned that household income does not correlate with either risk aversion (in terms of concavity of utility function) or loss aversion, we decomposed household income into two variables, mean village income and relative income within the village (subtracting the mean and dividing by the within-village standard deviation).

Columns 2 and 4 of Table 4 contain the regression results of the estimations. Neither relative income nor mean income of the village correlates with concavity of utility function. However, mean village income is strongly correlated with loss aversion. Nevertheless, income variables may be endogenous, and it is difficult to know whether they explain risk preferences, or vice versa. We used rainfall and household head's ability to work at the time of survey as exogenous

\footnotetext{
${ }^{7}$ The average estimated value of $\lambda$ is 2.63 , close to the 2.25 estimated by Tversky and Kahneman (1992), and is significantly different from one by $t$-test $(p<0.001)$. Liu's $(2008)$ estimate is 3.47 . For a further survey and evidence that loss aversion can be emotionally regulated, see Peter Sokol-Hessner et al. (2009).
} 


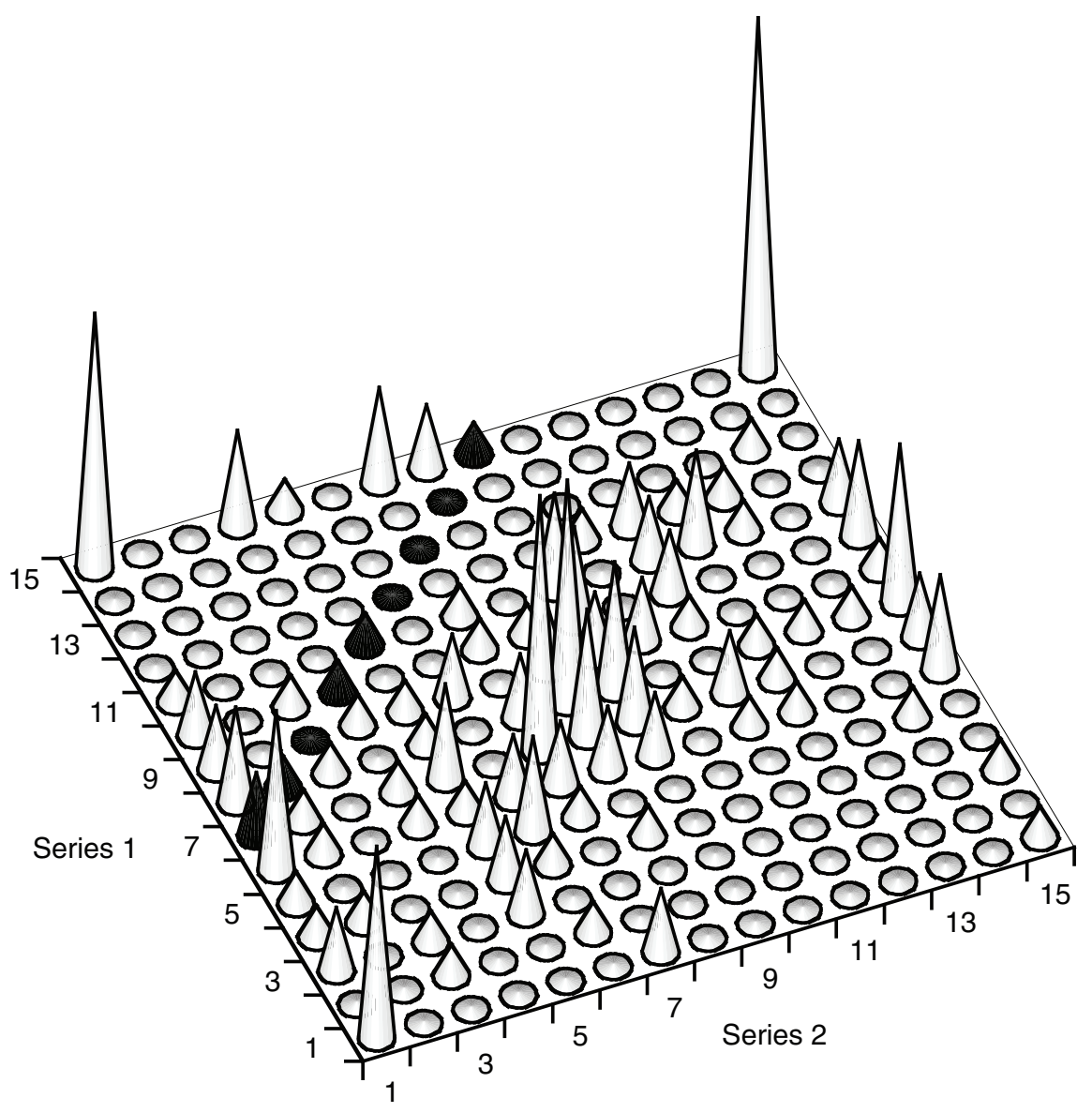

Figure 1. Distribution of Switching Points in Series 1 and 2

Notes: Experimental data. Black denotes switching point pairs consistent with EU.

instruments for income variables, ${ }^{8}$ and conducted the Hausman and Davidson-MacKinnon tests to investigate whether OLS is an inconsistent estimator for curvature of the utility function $(\sigma)$ and loss aversion $(\lambda)$. The results of both tests suggest OLS is an inconsistent estimator for $\sigma$ (see Table 4). Therefore, we conducted instrumental variable two-stage least squares (IV-2SLS) regressions for the curvature of the utility function $(\sigma)$. The IV regression results are shown in Table 5. The variable "head can't work" is a dummy variable, taking the value one if the household head was not able to work at the time of the survey. The effect of mean income is now significant at the 10 percent level, i.e., individuals living in wealthier villages are less loss averse and also less risk averse. There are no significant effects of gender, which is interesting because many studies find that men are less averse to financial risk than women (e.g., Catherine C. Eckel and Philip Grossman 2008). Our findings suggest that these previous effects of gender may be

\footnotetext{
${ }^{8}$ We tested several instrumental variables, e.g., funeral costs, natural disaster relief, crop failure due to natural disaster and pests, and selected rainfall and household head's ability to work as instruments, since these variables yield the highest $F$-statistic in the regression.
} 
Table 4-Correlations with Dimensions of Risk Aversion (OLS)

\begin{tabular}{|c|c|c|c|c|}
\hline & \multicolumn{4}{|c|}{ Dependent variable } \\
\hline & \multicolumn{2}{|c|}{$\sigma$ (Value function curvature) } & \multicolumn{2}{|c|}{$\lambda($ Loss aversion $)$} \\
\hline & (1) & (2) & (3) & (4) \\
\hline Chinese & $\begin{array}{c}0.039 \\
(0.115)\end{array}$ & $\begin{array}{c}0.027 \\
(0.121)\end{array}$ & $\begin{array}{c}-3.273^{*} \\
(1.711)\end{array}$ & $\begin{array}{c}-2.341 \\
(1.769)\end{array}$ \\
\hline Age & $\begin{array}{c}-0.005^{* *} \\
(0.002)\end{array}$ & $\begin{array}{c}-0.005^{* *} \\
(0.002)\end{array}$ & $\begin{array}{c}0.042 \\
(0.030)\end{array}$ & $\begin{array}{c}0.049 \\
(0.030)\end{array}$ \\
\hline Gender & $\begin{array}{c}-0.035 \\
(0.056)\end{array}$ & $\begin{array}{c}-0.028 \\
(0.056)\end{array}$ & $\begin{array}{c}-0.524 \\
(0.791)\end{array}$ & $\begin{array}{c}-0.557 \\
(0.781)\end{array}$ \\
\hline Education & $\begin{array}{c}-0.019^{* *} \\
(0.007)\end{array}$ & $\begin{array}{c}-0.020 * * * \\
(0.008)\end{array}$ & $\begin{array}{c}0.098 \\
(0.105)\end{array}$ & $\begin{array}{c}0.141 \\
(0.106)\end{array}$ \\
\hline Income & $\begin{array}{c}-0.001 \\
(0.001)\end{array}$ & & $\begin{array}{r}-0.028 \\
(0.017)\end{array}$ & \\
\hline Relative income & & $\begin{array}{c}-0.011 \\
(0.026)\end{array}$ & & $\begin{array}{r}-0.600 \\
(0.371)\end{array}$ \\
\hline Mean income & & $\begin{array}{r}0.000 \\
(0.003)\end{array}$ & & $\begin{array}{c}-0.086 * * \\
(0.043)\end{array}$ \\
\hline Distance to market & $\begin{array}{r}-0.008 \\
(0.014)\end{array}$ & $\begin{array}{r}-0.008 \\
(0.015)\end{array}$ & $\begin{array}{c}-0.178 \\
(0.206)\end{array}$ & $\begin{array}{c}-0.151 \\
(0.205)\end{array}$ \\
\hline South & $\begin{array}{r}-0.033 \\
(0.057)\end{array}$ & $\begin{array}{r}-0.052 \\
(0.064)\end{array}$ & $\begin{array}{c}1.479 * \\
(0.810)\end{array}$ & $\begin{array}{l}1.994^{* *} \\
(0.888)\end{array}$ \\
\hline Constant & $\begin{array}{l}1.054 * * * \\
(0.141)\end{array}$ & $\begin{array}{l}1.038^{* * * *} \\
(0.144)\end{array}$ & $\begin{array}{c}0.514 \\
(1.997)\end{array}$ & $\begin{array}{c}0.722 \\
(2.000)\end{array}$ \\
\hline $\begin{array}{l}\text { Observations } \\
R^{2}\end{array}$ & $\begin{array}{l}181 \\
0.07\end{array}$ & $\begin{array}{l}181 \\
0.06\end{array}$ & 181 & 181 \\
\hline $\begin{array}{l}\text { Log likelihood } \\
\text { Hausman test }\end{array}$ & $\begin{array}{c}\chi^{2}=5.23 \\
(p=0.022)\end{array}$ & $\begin{array}{c}\chi^{2}=5.52 \\
(p=0.063)\end{array}$ & $\begin{array}{c}-436 \\
\chi^{2}=0.27 \\
(p=0.999)\end{array}$ & $\begin{array}{c}-434 \\
\chi^{2}=3.33 \\
(p=0.853)\end{array}$ \\
\hline Davidson-MacKinnon test & $\begin{array}{c}F \text {-statistic } \\
=5.36 \\
(p=0.021)\end{array}$ & $\begin{array}{c}F \text {-statistic } \\
=2.82 \\
(p=0.063)\end{array}$ & $\begin{array}{c}\chi^{2}=0.06 \\
(p=0.814)\end{array}$ & $\begin{array}{l}\chi^{2}=0.87 \\
(p=0.814)\end{array}$ \\
\hline
\end{tabular}

Note: Standard errors are in parentheses.

*** Significant at the 1 percent level.

** Significant at the 5 percent level.

* Significant at the 10 percent level.

due to confounds with variables that often correlate with gender, such as income and education, which can be controlled for using our household survey.

\section{Time Discounting}

\section{A. Previous Findings}

Time discounting is another fundamental preference which may affect wealth accumulation. Most studies linking discount rates to wealth in both developed and developing societies use the exponential discounting model and show richer people are more patient (lower $r) .{ }^{9}$ However, the exponential discounting model is often rejected by experimental and field data (Frederick,

\footnotetext{
${ }^{9}$ Jerry Hausman (1979), Emily C. Lawrance (1991), and Glenn W. Harrison, Marten I. Lau and Melonie B. Williams (2002) report this relation in the United States and Denmark. John L. Pender (1996), Nielsen (2001), and Yesuf (2004) report it in India, Madagascar, and Ethiopia, respectively. Kris N. Kirby et al. (2002), and C. Leigh Anderson et al. (2004) did not find a wealth-patience relation in Bolivia and Vietnam, but their villages did not have as much income variation as we were able to design by handpicking villages.
} 
TABle 5-IV-2SLS Regressions for Risk Aversion $(\sigma)$

\begin{tabular}{|c|c|c|c|c|c|c|}
\hline \multicolumn{7}{|l|}{ First stage } \\
\hline & \multicolumn{6}{|c|}{ Dependent variable } \\
\hline & \multicolumn{2}{|c|}{ Income } & \multicolumn{2}{|c|}{ Relative income } & \multicolumn{2}{|c|}{ Mean income } \\
\hline Rainfall & 0.018 & $(0.006) * * *$ & -0.000 & $(0.000)$ & 0.019 & $(0.002) * * *$ \\
\hline Head of household can't work (dummy) & -11.846 & $(7.786)$ & -0.930 & $(0.380) * *$ & -2.869 & $(2.584)$ \\
\hline Chinese & 6.741 & $(6.824)$ & 0.196 & $(0.333)$ & 10.942 & $(2.265) * * *$ \\
\hline Age & 0.035 & $(0.128)$ & 0.003 & $(0.006)$ & 0.054 & $(0.042)$ \\
\hline Gender & -5.129 & $(3.282)$ & -0.012 & $(0.160)$ & -2.063 & $(1.089) *$ \\
\hline Education & 0.706 & $(0.440)$ & 0.036 & $(0.021) *$ & 0.281 & $(0.146) *$ \\
\hline Distance to market & -1.0673 & $(0.974)$ & 0.021 & $(0.048)$ & -1.137 & $(0.323) * * *$ \\
\hline South & 10.483 & $(3.277) * * *$ & -0.040 & $(0.160)$ & 9.340 & $(1.088) * * *$ \\
\hline Constant & -13.122 & $(10.671)$ & -0.179 & $(0.521)$ & -14.209 & $(3.541) * * *$ \\
\hline Observations & 181 & & 181 & & 181 & \\
\hline$R^{2}$ & 0.15 & & 0.05 & & 0.58 & \\
\hline$F$-statistic & 3.89 & & 1.17 & & 30.22 & \\
\hline
\end{tabular}

Second stage

Chinese

Age

Gender

Education

Income (IV)

Relative income (IV)

Mean income (IV)

Distance to market

South

Constant

\begin{tabular}{rlrl}
\multicolumn{5}{c}{ Dependent variable } \\
\hline \multicolumn{5}{c}{$\sigma$ (Value function curvature) } \\
\hline-0.035 & $(0.143)$ & -0.096 & $(0.138)$ \\
-0.006 & $(0.003) * *$ & -0.006 & $(0.002) * * *$ \\
0.022 & $(0.073)$ & -0.006 & $(0.059)$ \\
-0.029 & $(0.010) * * *$ & -0.028 & $(0.010) * * *$ \\
0.010 & $(0.006)$ & 0.049 & $(0.148)$ \\
& & 0.010 & $(0.005) *$ \\
-0.012 & $(0.017)$ & -0.013 & $(0.010)$ \\
-0.155 & $(0.094)$ & -0.148 & $(0.080) *$ \\
0.980 & $(0.174) * * *$ & 0.992 & $(0.160) * * *$
\end{tabular}

Observations

$R^{2}$

$181+181$

$\begin{array}{ll}0.08 & 0.08\end{array}$

Note: Standard errors are in parentheses.

*** Significant at the 1 percent level.

** Significant at the 5 percent level.

* Significant at the 10 percent level.

Loewenstein, and O'Donoghue 2002). For example, measured discount rates tend to decline over time $^{10}$ (George Ainslie 1992) and exhibit a "present bias" or preference for immediate reward. ${ }^{11}$ David Laibson (1997) proposed "quasi-hyperbolic" discounting model. ${ }^{12}$

\section{B. Measurement of Time Discounting Parameters}

We use a general model proposed by Benhabib, Bisin, and Schotter (2007), which allows us to test exponential, hyperbolic, quasi-hyperbolic discounting, and a more general form. The model

\footnotetext{
${ }^{10}$ See Richard Thaler (1981), Uri Benzion, Amnon Rapoport, and Joseph Yagil (1989), Loewenstein and Prelec (1992), and Pender (1996).

${ }^{11}$ See Laibson (1997), Laibson et al. (1998), O’Donoghue and Matthew Rabin (1999), and George-Marios Angeletos et al. (2001).

12 This formulation has been used to study retirement planning, gym membership, procrastination, deadlines, and addiction (B. Douglas Bernheim, Jonathan Skinner, and Stephen Weinberg 2001; Stefano DellaVigna and Ulrike Malmendier 2006; Peter Diamond and Botond Köszegi 2003; Laibson, Andrea Repetto, and Jeremy Tobacman 1998; O’Donoghue and Rabin 1999, 2001).
} 
Table 6-Comparison of Exponential, Hyperbolic, and Quasi-Hyperbolic Discounting Models

\begin{tabular}{lcccc}
\hline \hline & Exponential & Hyperbolic & Quasi-hyperbolic & Equation $(1)$ \\
\hline$\mu\left(\times 10^{-6}\right)$ & $6.26^{* * *}$ & $7.60^{* * *}$ & $8.58^{* * *}$ & $8.70 * * *$ \\
$r$ & $(0.319)$ & $(0.408)$ & $(0.544)$ & $(0.553)$ \\
$\beta$ & $0.021^{* * *}$ & $0.046^{* * *}$ & $0.008^{* * *}$ & 0.078 \\
$\theta$ & $(0.001)$ & $(0.004)$ & $(0.001)$ & $(0.074)$ \\
$\theta$ & & & $0.644 * * *$ & $0.820^{* * *}$ \\
& & & $(0.019)$ & $(0.070)$ \\
Observations & & & & $5.070^{* * *}$ \\
Adjusted $R^{2}$ & 5,340 & & & $0.659)$ \\
\hline
\end{tabular}

Notes: Robust standard errors are in parentheses. Standard errors are adjusted for within-subject correlations. *** Significant at the 1 percent level.

assigns a value to reward $y$ at time of $y \beta(1-(1-\theta) r t)^{1 /(1-\theta)}$ for $t>0$ (or simply $y$ for immediate reward at $t=0) \cdot{ }^{13}$

The three factors $r, \beta$, and $\theta$ separate conventional time discounting $(r)$, present-bias $(\beta)$, and hyperbolicity $(\theta)$ of the discount function. When $\beta=1$, as $\theta$ approaches one the discounted value reduces to exponential discounting $\left(e^{-r t}\right)$ in the limit. When $\theta=2$ and $\beta=1$, it reduces to true hyperbolic discounting $(1 /(1+r t))$. When $\theta=1$ (in the limit) and $\beta$ is free, it reduces to quasi-hyperbolic discounting $\left(\beta e^{-r t}\right)$. The three-parameter form enables a way to compare three familiar models at once.

In our experiments, subjects make 75 choices between smaller rewards delivered today and larger rewards delivered at specified times in the future as follows: Option A: receive $x$ dong today; or Option B: receive $y$ dong in $t$ days.

The reward $x$ varies between 30,000 to 300,000 and the time delay $t$ varies between three days and three months (see Table A2 in the Web Appendix). ${ }^{14}$

Before conducting the experiment, we chose and announced a trusted agent who would keep the money until delayed delivery date to ensure subjects believed the money would be delivered. The selected trusted persons were usually village heads or presidents of women's associations. In five villages, the trusted agents were also experimental subjects. Agreement letters of money delivery were signed between the trusted agents and the first author. Agents were instructed to deliver the money to the houses of experimental subjects, which tries to equalize the pure transaction costs of receiving money immediately (i.e., at the end of the experiment) or in the future. ${ }^{15}$

After subjects completed all 75 questions, we put 75 numbered balls in the bingo cage and drew one ball to determine a pairwise choice. The option chosen for that pair (i.e., A or B) determined how much money was to be delivered, and when.

\footnotetext{
${ }^{13}$ The original Benhabib-Bisin-Schotter model includes the present bias in the form of a fixed cost. Zafer Akin and Abdullah Yavas (2007) estimate the model and find the present bias parameter in the form of a fixed cost is not well supported by the data.

${ }^{14}$ The largest amount of $y, 300,000$ dong (about 19 dollars), is 15 days' wages in the rural north.

${ }^{15}$ A referee suggested appropriately cautious wording: "There are many risks involved with leaving the money with the village head; one is that the village head will give out the money early, another is that the village head will keep the money for himself, another is that the village head will encourage those players who will be receiving a lot of money in the future to redistribute it within the village as earnings are no longer anonymous. These issues may affect the values of $r, \beta$, and $\theta$ in different ways. Given the difficulties in experimental design we did the best we can, and these are interesting issues for future research."
} 
We denote the probability of choosing immediate reward of $x$ over the delayed reward of $y$ in $t$ days by $P(x>(y, t))$, and use a logistic function to describe this relation as follows:

$$
P(x>(y, t))=\frac{1}{1+\exp \left(-\mu\left(x-y \beta(1-(1-\theta) r t)^{1 / 1-\theta}\right)\right)}
$$

We estimate the parameters $\mu, \beta, \theta$, and $r$ in the logistic equation above. The variable $\mu$ is a response sensitivity or noise parameter.

\section{Empirical Results}

Estimation results comparing specific functions are given in Table 6. We fitted the logistic function (1) by using a nonlinear least-squares regression procedure. ${ }^{16}$ The estimated values of $(r, \beta, \theta)$ are $(0.078,0.82,5.07) .{ }^{17}$ This implies subjects should trade 6,151 dong today for 10,000 dong in a week, and 4,971 dong today for 10,000 dong in three weeks.

In addition to the general model (1) (shown in the far right column), we estimated exponential, hyperbolic, and quasi-hyperbolic discounting models. Estimating the full model (1) with unrestricted $\theta$ does not improve $R^{2}$ much compared with the estimation of the quasi-hyperbolic model, so we focus attention only on the quasi-hyperbolic discounting.

Next, we estimate the following logistic function (2) to see whether demographic variables correlate with individual difference in present bias $(\beta)$ and discount rates $(r)$ :

$$
P(x>(y, t))=\frac{1}{1+\exp (-\mu(x-y \beta \exp [-r t]))},
$$

where $\beta=\beta_{0}+\Sigma \beta_{i} X_{i}, r=r_{0}+\Sigma r_{i} X_{i}$, and demographic variables and associated coefficients are represented by $X_{i}$ and $\beta_{i}$ or $r_{i}$.

Table 7 shows the results from regressing estimates of the quasi-hyperbolic discounting model, allowing $\beta$ and $r$ to depend on demographic variables. We conducted nonlinear estimations of the logistic function (2), using household income as an independent variable for the first regression (reported in column (1)), and relative and mean village income as independent variables for the second regression (reported in column (2))..$^{18}$ The variable "trusted agent" is a dummy variable, taking the value 1 if the subject is a trusted agent for money delivery. The variable "risk payment" corresponds to the amount of money the subject received in the risk experiment.

The largest effects are on discount rates $r$. Household income and mean village income are positively related with patience (lower $r$ ). None of the income variables explains individual difference in present bias $(\beta)$ while the estimated coefficient of $\beta$ in Table 6 (0.644) indicates subjects are present biased. This implies people are present biased regardless of their wealth, and the degree of present bias is comparable to estimates from a variety of other studies. ${ }^{19}$

\footnotetext{
${ }^{16}$ We excluded data from three subjects who made alternating responses across consecutive rows.

${ }^{17} t$-tests of $\theta=1$ (quasi-hyperbolic discounting) and each of the restrictions $\beta=\theta=1$ (exponential discounting) and $\beta=1$ and $\theta=2$ (hyperbolic discounting) reject all restrictions at $p>0.0001$.

${ }_{18}^{18}$ The coefficients of explanatory variables for $r$ (discount rates) are multiplied by 100 .

${ }^{19}$ See Alexander L. Brown, Camerer, and Zhikang Eric Chua (2009) for a review of quasi-hyperbolic model estimates.
} 
Table 7-Correlations with Present Bias and Discount Rates (OLS)

\begin{tabular}{|c|c|c|c|c|}
\hline \multirow[b]{3}{*}{$\mu\left(\mathrm{x} 10^{-6}\right)$} & \multicolumn{2}{|c|}{$\beta$ (Present bias) } & \multicolumn{2}{|c|}{$r$ (Discount rate) } \\
\hline & (1) & (2) & (1) & (2) \\
\hline & $\begin{array}{l}8.93 * * * \\
(0.59)\end{array}$ & $\begin{array}{l}9.14 * * * \\
(0.61)\end{array}$ & & \\
\hline Constant $\left(\beta_{0}, r_{0}\right)$ & $\begin{array}{l}0.673^{* * *} \\
(0.096)\end{array}$ & $\begin{array}{l}0.676^{* * * *} \\
(0.098)\end{array}$ & $\begin{array}{l}0.021^{* * * *} \\
(0.004)\end{array}$ & $\begin{array}{l}0.023^{* * *} \\
(0.004)\end{array}$ \\
\hline Chinese & $\begin{array}{c}-0.037 \\
(0.086)\end{array}$ & $\begin{array}{r}-0.046 \\
(0.089)\end{array}$ & $\begin{array}{c}-0.199 \\
(0.337)\end{array}$ & $\begin{array}{c}-0.019 \\
(0.316)\end{array}$ \\
\hline Trusted agent & $\begin{array}{c}-0.043 \\
(0.080)\end{array}$ & $\begin{array}{c}-0.032 \\
(0.080)\end{array}$ & $\begin{array}{c}-0.189 \\
(0.265)\end{array}$ & $\begin{array}{c}0.085 \\
(0.293)\end{array}$ \\
\hline Age & $\begin{array}{c}0.001 \\
(0.002)\end{array}$ & $\begin{array}{c}0.001 \\
(0.002)\end{array}$ & $\begin{array}{c}-0.013 * * \\
(0.005)\end{array}$ & $\begin{array}{c}-0.012^{* *} \\
(0.005)\end{array}$ \\
\hline Gender & $\begin{array}{c}0.013 \\
(0.039)\end{array}$ & $\begin{array}{c}0.015 \\
(0.039)\end{array}$ & $\begin{array}{r}-0.122 \\
(0.141)\end{array}$ & $\begin{array}{c}-0.121 \\
(0.130)\end{array}$ \\
\hline Education & $\begin{array}{r}-0.009 \\
(0.005)\end{array}$ & $\begin{array}{r}-0.009 \\
(0.006)\end{array}$ & $\begin{array}{c}-0.037 * * \\
(0.017)\end{array}$ & $\begin{array}{r}-0.023 \\
(0.015)\end{array}$ \\
\hline Income & $\begin{array}{c}0.510 \\
(0.658)\end{array}$ & & $\begin{array}{c}-4.530^{* *} \\
(1.782)\end{array}$ & \\
\hline Relative income & & $\begin{array}{r}0.000 \\
(0.019)\end{array}$ & & $\begin{array}{c}0.016 \\
(0.065)\end{array}$ \\
\hline Mean village income & & $\begin{array}{c}1.196 \\
(2.381)\end{array}$ & & $\begin{array}{c}-29.838^{* * *} * \\
(7.512)\end{array}$ \\
\hline Distance to market & $\begin{array}{c}0.013 \\
(0.012)\end{array}$ & $\begin{array}{c}0.013 \\
(0.012)\end{array}$ & $\begin{array}{r}-0.010 \\
(0.037)\end{array}$ & $\begin{array}{c}0.000 \\
(0.034)\end{array}$ \\
\hline South & $\begin{array}{c}-0.053 \\
(0.046)\end{array}$ & $\begin{array}{r}-0.059 \\
(0.050)\end{array}$ & $\begin{array}{c}-0.153 \\
(0.152)\end{array}$ & $\begin{array}{r}0.080 \\
(0.163)\end{array}$ \\
\hline Risk payment & $\begin{array}{r}-0.819 \\
(1.011)\end{array}$ & $\begin{array}{r}-0.928 \\
(1.015)\end{array}$ & $\begin{array}{c}-7.144 * * \\
(3.593)\end{array}$ & $\begin{array}{c}-4.115 \\
(3.602)\end{array}$ \\
\hline $\begin{array}{l}\text { Observations } \\
\text { Adjusted } R^{2} \\
\text { Davidson and MacKinnon test }\end{array}$ & $\begin{array}{c}5,340 \\
0.52 \\
F \text {-statistic } \\
=4.58 \\
(p=0.011)\end{array}$ & $\begin{array}{c}5,340 \\
0.52 \\
F \text {-statistic } \\
=3.18 \\
(p=0.014)\end{array}$ & & \\
\hline
\end{tabular}

Notes: Standard errors are in parentheses. Standard errors are adjusted for within-subject correlations. The estimated coefficients of explanatory variables for $r$ (discount rates) are multiplied by 100 .

*** Significant at the 1 percent level.

** Significant at the 5 percent level.

* Significant at the 10 percent level.

The amount of money made in the risk game earlier in the experimental session is weakly correlated with patience: individuals who received higher payments in the risk game exhibit lower discount rates $r$. The choices made by the individuals who were assigned the role of money delivery were not significantly different from those of other subjects. ${ }^{20} \mathrm{We}$ also conducted regressions using instrumental variables (IV) for income variables, because the results of the Davidson-MacKinnon test suggest OLS is an inconsistent estimator. Table 8 shows the regression results from the IV estimations. It indicates household income, as well as a mean village income correlate with lower discount rates.

\footnotetext{
${ }^{20} \mathrm{We}$ also conducted regressions without the data of the five subjects who were assigned the role of money delivery. There were few changes in regression results (see Web Appendix Table A3).
} 
Table 8-Correlations with Present Bias and Discount Rates (IV-2SLS)

\begin{tabular}{|c|c|c|c|c|}
\hline \multirow[b]{3}{*}{$\mu\left(\mathrm{x} 10^{-6}\right)$} & \multicolumn{2}{|c|}{$\beta$ (Present bias) } & \multicolumn{2}{|c|}{$r($ Discount rate $)$} \\
\hline & (3) & (4) & (3) & (4) \\
\hline & $\begin{array}{l}9.09 * * * \\
(0.61)\end{array}$ & $\begin{array}{l}9.09 * * * \\
(0.18)\end{array}$ & & \\
\hline Constant $\left(\beta_{0}, r_{0}\right)$ & $\begin{array}{l}0.664 * * * \\
(0.098)\end{array}$ & $\begin{array}{l}0.643^{* * * *} \\
(0.113)\end{array}$ & $\begin{array}{l}0.024 * * * \\
(0.004)\end{array}$ & $\begin{array}{l}0.023^{* * * *} \\
(0.004)\end{array}$ \\
\hline Chinese & $\begin{array}{c}-0.055 \\
(0.078)\end{array}$ & $\begin{array}{r}-0.086 \\
(0.106)\end{array}$ & $\begin{array}{c}-0.023 \\
(0.337)\end{array}$ & $\begin{array}{l}0.161 \\
(0.358)\end{array}$ \\
\hline Trusted agent & $\begin{array}{c}-0.039 \\
(0.078)\end{array}$ & $\begin{array}{c}-0.065 \\
(0.075)\end{array}$ & $\begin{array}{c}-0.334 \\
(0.223)\end{array}$ & $\begin{array}{c}-0.147 \\
(0.239)\end{array}$ \\
\hline Age & $\begin{array}{r}0.000 \\
(0.001)\end{array}$ & $\begin{array}{r}0.000 \\
(0.001)\end{array}$ & $\begin{array}{c}-0.015^{* * *} \\
(0.006)\end{array}$ & $\begin{array}{c}-0.013 * * \\
(0.006)\end{array}$ \\
\hline Gender & $\begin{array}{c}0.037 \\
(0.045)\end{array}$ & $\begin{array}{c}0.032 \\
(0.040)\end{array}$ & $\begin{array}{r}-0.162 \\
(0.140)\end{array}$ & $\begin{array}{c}-0.051 \\
(0.140)\end{array}$ \\
\hline Education & $\begin{array}{c}-0.012 \\
(0.007)\end{array}$ & $\begin{array}{c}-0.010 \\
(0.008)\end{array}$ & $\begin{array}{r}-0.002 \\
(0.020)\end{array}$ & $\begin{array}{r}-0.019 \\
(0.022)\end{array}$ \\
\hline Income (IV) & $\begin{array}{l}3.801 \\
(4.497)\end{array}$ & & $\begin{array}{c}-38.985^{* * * *} \\
(13.313)\end{array}$ & \\
\hline Relative income (IV) & & $\begin{array}{r}-0.044 \\
(0.144)\end{array}$ & & $\begin{array}{r}-0.128 \\
(0.437)\end{array}$ \\
\hline Mean village income (IV) & & $\begin{array}{c}5.994 \\
(4.878)\end{array}$ & & $\begin{array}{c}-36.264 * * \\
(14.907)\end{array}$ \\
\hline Distance to market & $\begin{array}{c}0.012 \\
(0.012)\end{array}$ & $\begin{array}{c}0.010 \\
(0.012)\end{array}$ & $\begin{array}{c}0.034 \\
(0.039)\end{array}$ & $\begin{array}{c}0.034 \\
(0.040)\end{array}$ \\
\hline South & $\begin{array}{c}-0.081 \\
(0.060)\end{array}$ & $\begin{array}{r}-0.091 \\
(0.055)\end{array}$ & $\begin{array}{r}0.239 \\
(0.213)\end{array}$ & $\begin{array}{c}0.176 \\
(0.212)\end{array}$ \\
\hline Risk payment & $\begin{array}{r}-1.078 \\
(1.104)\end{array}$ & $\begin{array}{r}-1.605 \\
(1.417)\end{array}$ & $\begin{array}{r}-5.404 \\
(3.993)\end{array}$ & $\begin{array}{c}-5.022 \\
(4.4507)\end{array}$ \\
\hline $\begin{array}{l}\text { Observations } \\
\text { Adjusted } R^{2}\end{array}$ & $\begin{array}{c}5,340 \\
0.52\end{array}$ & $\begin{array}{c}5,340 \\
0.52\end{array}$ & & \\
\hline
\end{tabular}

Notes: Standard errors are in parentheses. We adjusted standard errors for correlations within individuals. The estimated coefficients of explanatory variables for $r$ (discount rates) are multiplied by 100 .

*** Significant at the 1 percent level.

** Significant at the 5 percent level.

* Significant at the 10 percent level.

\section{Conclusion}

We conducted experiments in Vietnamese villages to investigate how income and other demographic variables are correlated with risk and time preference.

Our results suggest mean village income is related to risk and time preferences. People living in poor villages are not necessarily afraid of uncertainty, in the sense of income variation; instead, they are averse to loss. When we introduce instrumental variables for income variables, mean village income is also significantly correlated with risk aversion (concavity of the utility function). From the time discounting experiment, we found that mean village income is correlated with lower discount rates, that is, people living in wealthy villages are not only less risk averse but also more patient.

Household income is correlated with patience (lower interest rate) but not with risk preference, which is consistent with the classic result of Binswanger $(1980,1981)$. Our results also demonstrate that people are present biased regardless of their income levels and economic environments.

These results are exploratory and the experimental measures are not perfect. Furthermore, in a cross-sectional study like this, it is difficult to conclude much about the direction of causality between preferences and economic circumstances because the study was not designed to do so. 
We used instrumental variables to deal with the income endogeneity problem. However, preferences and circumstances may be causal in both directions.

Finally, one contribution of our study is to show how to expand measurements of risk and time preferences beyond one-parameter expected utility and exponential discounting, replacing those models with prospect theory and the Benhabib et al. three-parameter discounting model. The parameters we measure are comparable to those in other studies (particularly the first direct replication using our risk preference measurement method, by Liu (2008) studying Chinese farmers) and correlate in interesting ways with household measures.

\section{REFERENCES}

Ainslie, George. 1992. Picoeconomics: The Strategic Interaction of Successive Motivational States within the Person. New York: Cambridge University Press.

Akin, Zafer, and Abdullah Yavas. 2007. "An Experimental Analysis of Time-Inconsistency in Long-Run Projects," Unpublished.

Anderson, C. Leigh, Maya Dietz, Andrew Gordon, and Marieka Klawitter. 2004. "Discount Rates in Vietnam." Economic Development and Cultural Change, 52(4): 873-87.

-Angeletos, George-Marios, David Laibson, Andrea Repetto, Jeremy Tobacman, and Stephen Weinberg. 2001. "The Hyberbolic Consumption Model: Calibration, Simulation, and Empirical Evaluation." Journal of Economic Perspectives, 15(3): 47-68.

Ashraf, Nava, Dean Karlan, and Wesley Yin. 2006. "Tying Odysseus to the Mast: Evidence from a Commitment Savings Product in the Philippines." Quarterly Journal of Economics, 121(2): 635-72.

Benhabib, Jess, Alberto Bisin, and Andrew Schotter. 2007. "Hyperbolic Discounting: An Experimental Analysis." http://homepages.nyu.edu/ as7/pshype1205withfigures.pdf.

-Benzion, Uri, Amnon Rapoport, and Joseph Yagil. 1989. "Discount Rates Inferred from Decisions: An Experimental Study." Management Science, 35(3): 270-84.

- Bernheim, B. Douglas, Jonathan Skinner, and Stephen Weinberg. 2001. "What Accounts for the Variation in Retirement Wealth among US Households?" American Economic Review, 91(4): 832-57.

-Binswanger, Hans P. 1980. "Attitudes toward Risk: Experimental Measurement in Rural India." American Journal of Agricultural Economics, 62(3): 395-407.

-Binswanger, Hans P. 1981. "Attitudes toward Risk: Theoretical Implications of an Experiment in Rural India.” Economic Journal, 91(364): 867-90.

Bowles, Samuel. 1998. "Endogenous Preferences: The Cultural Consequences of Markets and Other Economic Institutions." Journal of Economic Literature, 36(1): 75-111.

-Brown, Alexander L., Colin F. Camerer, and Zhikang Eric Chua. 2009. "Learning and Visceral Temptation in Dynamic Saving Experiments." Quarterly Journal of Economics, 124(1): 197-231.

Camerer, Colin F. 2000. "Prospect Theory in the Wild: Evidence from the Field." In Choices, Values, and Frames, ed. D. Kahneman and A. Tversky, 288-300. Cambridge: Cambridge University Press.

-Cardenas, Juan-Camilo, and Jeffrey Carpenter. 2008. "Behavioural Development Economics: Lessons from Field Labs in the Developing World." Journal of Development Studies, 44(3): 311-38.

-DellaVigna, Stefano, and Ulrike Malmendier. 2006. "Paying Not to Go to the Gym." American Economic Review, 96(3): 694-719.

DDiamond, Peter, and Botond Kôszegi. 2003. "Quasi-hyperbolic Discounting and Retirement." Journal of Public Economics, 87(9-10): 1839-72.

Duflo, Esther. 2005. "Field Experiments in Development Economics." Paper presented at World Congress of the Econometric Society 2005, London.

Eckel, Catherine C., and Philip Grossman. 2008. "Differences in the Economic Decisions of Men and Women: Experimental Evidence." In Handbook of Experimental Economics Results. Vol. 1, ed. Charles Plott and Vernon L. Smith, 509-19. New York: Elsevier.

-Frederick, Shane, George Loewenstein, and Ted O'Donoghue. 2002. "Time Discounting and Time Preference: A Critical Review." Journal of Economic Literature, 40(2): 351-401.

-Harrison, Glenn W., Morten I. Lau, and Melonie B. Williams. 2002. "Estimating Individual Discount Rates in Denmark: A Field Experiment.” American Economic Review, 92(5): 1606-17.

-Hausman, Jerry A. 1979. "Individual Discount Rates and the Purchase and Utilization of Energy-Using Durables." Bell Journal of Economics, 10(1): 33-54. 
Hsu, Ming, Ian Krajbich, Chen Zao, and Colin F. Camerer. 2009. "Neural Response to Reward Anticipation under Risk is Nonlinear in Probabilities." Journal of Neuroscience, 29(7): 2231-37.

-Kahneman, Daniel, and Amos Tversky. 1979. "Prospect Theory: An Analysis of Decision Under Risk." Econometrica, 47(2): 263-91.

Kanbur, Ravi, and Lyn Squire. 2001. "The Evolution of Thinking about Poverty: Exploring the Interactions." In Frontiers of Development Economics: The Future in Perspective, ed. G. M. Meier and J. E. Stiglitz, 183-226. Oxford: Oxford University Press.

- Kirby, Kris N., Ricardo Godoy, Victoria Reyes-Garcia, Elizabeth Byron, Lilian Apaza, William Leonard, Eddy Perez, Vincent Vadez, and David Wilkie. 2002. "Correlates of Delay-Discount Rates: Evidence from Tsimane' Amerindians of the Bolivian Rain Forest." Journal of Economic Psychology, 23(3): 291-316.

-Laibson, David. 1997. "Golden Eggs and Hyperbolic Discounting." Quarterly Journal of Economics, 112(2): 443-77.

Laibson, David, Andrea Repetto, and Jeremy Tobacman. 1998. "Self-Control and Saving for Retirement." Brookings Papers on Economic Activity, 29(1): 91-172.

Lawrance, Emily C. 1991. "Poverty and the Rate of Time Preference: Evidence from Panel Data." Journal of Political Economy, 99(1): 54-77.

Liu, Elaine. 2008. "Time to Change What to Sow: Risk Preferences and Technology Adoption Decisions of Cotton Farmers in China." http://www.class.uh.edu/econ/faculty/emliu/adoption.pdf.

Loewenstein, George, and Drazen Prelec. 1992. "Anomalies in Intertemporal Choice: Evidence and an Interpretation." Quarterly Journal of Economics, 107(2): 573-97.

-Mosley, Paul, and Arjan Verschoor. 2005. "Risk Attitudes and the 'Vicious Circle of Poverty."” European Journal of Development Research, 17(1): 59-88.

Nielsen, Uffe. 2001. "Poverty and Attitudes Towards Time and Risk: Experimental Evidence from Madagascar." http://www.environmental-economics.dk/papers/PTR-experim.pdf.

O'Donoghue, Ted, and Matthew Rabin. 1999. “Doing It Now or Later.” American Economic Review, 89(1): $103-24$.

O'Donoghue, Ted, and Matthew Rabin. 2001. "Choice and Procrastination." Quarterly Journal of Economics, 116(1): 121-60.

- Pender, John L. 1996. "Discount Rates and Credit Markets: Theory and Evidence from Rural India." Journal of Development Economics, 50(2): 257-96.

Drelec, Drazen. 1998. "The Probability Weighting Function." Econometrica, 66(3): 497-527.

- Rosenzweig, Mark R., and Hans P. Binswanger. 1993. "Wealth, Weather Risk and the Composition and Profitability of Agricultural Investments." Economic Journal, 103(416): 56-78.

-Sokol-Hessner, Peter, Ming Hsu, Nina G. Curley, Mauricio R. Delgado, Colin F. Camerer, and Elizabeth A. Phelps. 2009. "Thinking Like a Trader Selectively Reduces Individuals' Loss Aversion." PNAS, 106(13): 5035-40.

-Starmer, Chris. 2000. "Developments in Non-expected Utility Theory: The Hunt for a Descriptive Theory of Choice under Risk." Journal of Economic Literature, 38(2): 332-82.

-Thaler, Richard. 1981. "Some Empirical-Evidence on Dynamic Inconsistency." Economics Letters, 8(3): 201-07.

- Tversky, Amos, and Daniel Kahneman. 1992. "Advances in Prospect Theory: Cumulative Representation of Uncertainty." Journal of Risk and Uncertainty, 5(4): 297-323.

-Wik, Mette, Tewodros Aragie Kebede, Olvar Bergland, and Stein Holden. 2004. "On the Measurement of Risk Aversion from Experimental Data." Applied Economics, 36(21): 2443-51.

Yesuf, Mahmud. 2004. "Risk, Time and Land Management under Market Imperfections: Applications to Ethiopia." PhD diss. Göteborg University. 
This article has been cited by:

1. QUANG NGUYEN, PINGSUN LEUNG. 2010. How nurture can shape preferences: an experimental study on risk preferences of Vietnamese fishers. Environment and Development Economics 15:05, 609-631. [CrossRef] 